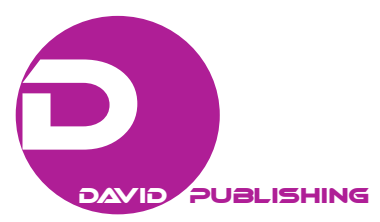

\title{
Collective Action and Networks in Civil Society: The Case of South Korea's Protest Movement
}

\author{
YunJoo Lee \\ Seoul National University, Seoul, Korea
}

\begin{abstract}
The Free Trade Agreement (FTA) was nearly ratified by United States and South Korea countries' administrations and can be described as a network of transnational trade. However, the candlelight protests have been held that network was set between the individuals of the South Korean society as a reaction against the FTA and Korean government. The network was the results of a new method of amassing power which comparing past protest in South Korea, and it was able to deal a severe blow to the ongoing FTA negotiations. In this paper, we will be using the actor-network theory (ANT) set forth by Law (1992) and Latour (2005) to explain Korean candlelight protest situations. A key claim is that ANT must range beyond studies of science and technology to other "social" subjects because it raises much broader questions about the construction of the social and nature. Therefore, this paper focused more on how the public opinion was aggregate in the social process, rather than the result. And we can see that the role of non-human actors is highly important. Through this attempt the citizen can reveal undisclosed information and get power to have communication with the government.
\end{abstract}

Keywords: actor-network theory, collective action, Free Trade Agreement (FTA), candlelight protest, South Korea

\section{Introduction}

Since 2003, the move towards the United States and South Korea Free Trade Agreement (FTA) has reinforced an already tight relationship between the two governments while talking a big step towards further integration. The FTA was nearly ratified by both countries' administrations and can be described as a network of transnational trade. However, the candlelight protests during 2008 have shown that network was created between the individuals of the South Korean society as a reaction to the FTA. The new network was the results of a revolutionary method of amassing power, and it was able to deal a severe blow to the ongoing FTA negotiations.

The South Korean network engaged the uninformed masses in the FTA negotiation process through internet cafes, Twitter, and web blogs, allowing for civil mobilization powerful enough to disrupt the outcome of a transnational issue (i.e. the FTA agreement). This has some similarity with the "Arab Spring" that social media networks played an important role in the rapid disintegration of at least two regimes, Tunisia and Egypt. Information Communication Technology (ICT) had little to do with the underlying sociopolitical and socioeconomic factors behind the protest movement (Stepanova, 2011).

These bring up some interesting questions: (1) Can ICT i.e., Internet, or Social Network Service (SNS) produce a public network strong enough to impact the sovereignty of a nation-state and produce a new form of

YunJoo Lee, Ph.D. candidate, Department of Social Studies Education, Seoul National University. 
shared governance? (2) How does Korean civil society communicate and aggregate political information through a network? (3) How does public opinion translate into collective action against the government by a non-human actor?

These questions allow me to answer regarding how individuals aggregate their public opinion. For instance, individuals communicate the political information and knowledge online or via real life network. Then, they also help specify the networks beyond which expresses their social capitals by media and collective action. That is to say, how the on-line networks of social relations provide social capital for civic participation. This is my concern which is with social network relevant to political engagement. Therefore, this paper uses an actor-network theory (ANT) framework to explain the social communication process during this protest movement.

This paper is divided into four main sections: (1) This study will explain the ANT as a main framework of study; (2) This study looks into the network dynamics between the Korean government and the citizens who represent the hubs interacting with each other in the FTA negotiations; (3) It will observe the results after revealing the black box, and finally; and (4) I will discuss the process of the formation of network using a non-human actors against the government.

\section{Explaining the Candlelight Protests Using Actor-Network Theory}

First, we will be using the ANT set forth by Law (1992) and Latour (2005) to explain Korean candlelight protest situations; especially, the South Korean public which became networked together using the internet and the way they took part in the genuine demonstrations on the streets of Seoul. A key claim in the literature is that ANT must range beyond studies of science and technology to other "social" subjects because it raises much broader questions about the construction of the social and nature. The key tenet of ANT is that the social cannot be presumed. Networks are the summation of a variety of different devices, not just human interactions, which operate through "flow of translations"; networks also involve interactions between objects, the actors, which are not necessarily human (Cowen \& Carr, 2008).

Previous studies on the candlelight protests in South Korea touch upon a number of topics ranging from explaining of a protest event, including direct democracy, the Internet revolution, the power of the masses, distrust of the government, and new form of mass demonstrations, to anti-Americanism. However, there has been hardly extensive research conducted on these subjects using the ANT. The core traits of ANT can be analysis not only links among persons but also among persons and things (non-human actor). If you are interested in collective action, think of a collective actor in which the capacity to be strategic cannot be assigned as an emergent effect of patterns of association in a much more heterogeneous network. Also, the actor network is realized through the common "enrolling" of human and non-human participants into a network through process of "negotiation" and "translation" (Law \& Hassard, 1999). Especially, the ANT allows us to analyze the dynamics of how the networks between Korea governments and citizen network through the Internet were brought into existence in this paper.

ANT can explain regulations, harmony, structure of networks, and opposing forces and how they are constantly being formed, dissipated and remade. Usually some actors must be present in order to form such networks. These Actors are "entities that do things" which can be represented by human agents such as governments or nation-states (Latour, 2005). Networks are other important theme of the ANT.

Callon (1986) also described a network as a "group of unspecified relationships" among entities which the 
nature itself is undetermined. Network ties together two systems of alliance which are humans and non-humans. The actors and network are mutually constitutive and cannot work without the other. These actors can be represented by nodes which interact and reciprocate with one another through forming "link". A single node becomes active enough by sharing the information and connecting with other nodes, and can be very well described as "hub". A hub is described as a central node which takes on multiple roles and actions and has a high degree of influence over other nodes surrounding. As we shall observe, the relationship among South Korea government, citizen and media can be explained by this concept of hubs and links.

Networks do not always have to depend on mere nodes or large, central hubs. A loose, yet large group of nodes, when brought together and mobilized collectively, can display of power over other actors through their sheer numbers. This collection of nodes in itself can also be viewed as an actor which can influence other nodes and even hubs. These nodes can use non-actors such as their surroundings in order to mobilize as a network and exert force. This will be explained in the section regarding how the South Korean public used the internet as their means to mobilize themselves to protest against the government.

The ANT reveals that people not only form networks face to face, but also use non-human elements which are referred to as "translation". For instance, people can use tools such as mobile and smart phones, computers, internet and trade agreements which are non-human materials in order to network with each other. In this study, we will see how the South Korean multitudes were able to resort to creating their own networks using their own respective non-human agents. In this regard, power is another important factor which must be mentioned in light of the ANT. Power in this paper will be represented by knowledge, which refers to the specific knowledge passed back and forth between the US and South Korean governments during the FTA negotiations which were hardly revealed to the public. This would leave a deep imprint of distrust in the minds of South Koreans towards President Lee which would lead them to exert power against his administration.

The new bigger network is the South Korea public, represented by individuals as nodes, which was being brought together through the internet forum. This network could now act collectively and exert a force powerful enough to oppose the ongoing FTA network through demonstrations. Though the candlelight protests were directed mainly at the South Korean president and his administration due to mistrust, the ongoing FTA negotiations, and network process would be dealt a severe blow. Also, a miscommunication between the masses and the government was clearly revealed during the candlelight protests.

Using the language of ANT, this entails how human actors utilize non-human agents (media and social network service) to produce a network such as the use of TV, newspaper, smart-phones, internet, and computers in a process known as "translation" (Latour, 2005). The ANT goes even further and shows how well-developed networks process power, represented by knowledge, which can exert upon other actors, including networks. This can be seen when the Korean civil society were able to unleash a force of opposition towards the Lee administration and more broadly the ongoing FTA negotiations. Then, it is also useful in this regard since most Koreans felt denied the knowledge of negotiations conducted between the two governments shrouded in secrecy but nevertheless was deemed as a Free Trade Agreement which would somehow benefit both nations. The civic of Koreans who would come together through the Internet forums, mobilize together, and protest on the streets of Seoul, would try to pry this network in the name of transparency. It shared norm or practices that enables network members to gain access to one another, facilitating their cooperation which creates a standard (Moaz, 2004; Miles, 2009). During the candlelight protests, Internet forums would become the standard in which people could come together and share ideas. 


\section{The US and South Korea Network Dynamics and the FTA}

South Korea is a major economic partner for the United States. In 2005, two-way trade between the two countries was nearly $\$ 70$ billion, making South Korea the seventh-largest trading partner of the United States, ahead of France and Italy. South Korea is among the United States' largest markets for agricultural products. Major US exports to South Korea include semiconductors, machinery (particularly semiconductor production machinery), aircraft, and agricultural products (Manyin \& Cooper, 2006).

The US International Trade Commission analyzed the South Korean and US FTA soon after its signing and the conclusion of the pact, if enacted, would likely increase US GDP by $\$ 10.1-\$ 11.9$ billion as a result of tariff and tariff-rate quota (TRQ) provisions related to goods market access. US merchandise exports to Korea would likely increase by an estimated $\$ 9.7-\$ 10.9$ billion, and US merchandise imports from Korea would likely increase by about $\$ 6.4-\$ 6.9$ billion as a result of tariff and TRQ provisions included in the pact. The report also estimated that US services exports would increase somewhat as a result of FTA provisions on market access, national treatment, and regulatory transparency although the overall impact of service liberalization on US output would not be significant given the relatively small size of US services trade with Korea (Bernard, Jensen, Redding, \& Schott, 2009).

The two governments were the actors which exercised the networking power of negotiations at this point of time. FTAs have been known to be handled directly between the governments of states themselves, though in many countries the public does have some leverage in participating during the FTA process, the power of trade agreements has been driven by the governments which have been the main actors behind such a trade networks. However, the knowledge being transmitted back and forth between the two governments was largely hidden from the view of the South Korean people, which could be referred in this study as the "black box". The black box refers to the negotiation process where the politicians and experts possessed the knowledge among them and were a complete mystery to the Korean public trying to peer in. Nonetheless, the government tried to package and portrays the "Free Trade Agreement" to the Korean people pleasantly which would supposedly benefit both countries.

In reality, however, the FTA was practically thrust onto the Korean people with minimal regard to their opinion or safety simply in the name of "free trade". From the onset of his election, President Lee Myung-bak was a strong advocate of stimulating the Korean economy by pursuing strong neo-liberal policies, job creation, economic growth and freer trade. President Lee simply assumed and proclaimed that the FTA was necessary for its "national interest" and pushed for ratification with the US. He also made claims that he would provide the losers of FTA, namely Korean farmers, with a compensation policy but did not provide any concrete strategies or convincing details to back his statements. Furthermore, the issue agricultural products would affect the Korean multitudes since they were ultimately the consumers of products sold by the farmers. Regardless, President Lee turned blind eye to public opinion in pushing the FTA agenda and did not provide sufficient consultation or set measures to survey the general public. This incited a flame of much uneasiness and anger amongst the Korean people since the government was neglecting the very safety of its citizens (Kim, 2008).

\section{The Structure Networking of the Korean Public}

\section{Through the ICT Including Media as Non-human Actor}

\section{Structural Hole}

If the state does not embody the collective will of the people-if it relies on exclusion or distortion which the people 
have not consented to - then this states is not legitimate. (Anderson, Dean, \& Lovink, 2006, p. xx)

The public network brings us to the formation of a set of network dynamics in which individuals of the Korean multitude acted collectively to form a massive network actor through the Internet. As in most developing countries, rapid technological development has long been one of the most urgent collective goals in Korea. Since the 1980s, through the intervention of the state, Korean society has embarked on an accelerated process of "technological modernization" with the expectation that such processes will change fate of the economy, national military power, and social well being in the face of global flows (Castells, 2009; Choi, 2008; Lee, 2010) .

In Korea, it is also possible to develop an ICT and new media to aggregate the public opinion and power against government. In particular, after the 1997 economic crisis, this techno-nationalistic discourse acquired a stronger voice and underscored overall cultural efforts to implement innovative new media services based on ICTs (Lee, 2010). Korea has been developed with the world's fastest ICT sector in the world and has also been at the forefront of diverse digital and electronic products. Korea's ICT and the advent of Web 2.0 have revolutionized the ease of communication and networking between nodes of people, especially in South Korea which boasts the fastest internet connection speed in the world. Whereas in the past Web 1.0 could allow a sender to pass information to the other end of a receiver, Web 2.0 allowed both sides to reciprocate and exchange information. This technology would lead to the greater diffusion, sharing, and speeding the information transmit between individuals among the public.

According to recent estimations, South Korean Internet users access the Internet usage rate from home computers $(96.3 \%)$, or from work $(33.1 \%)$, the highest in the world, over one million domain names, and a household broadband penetration of 97\%, 36.5 million people use the Internet, and 20 million people belong to Internet social networking sites. Also, accessing wireless Internet through mobile phones is increasing, with 4.2 million subscribers in 2008 (Lee, 2007).

Utilizing the translation process put forth by the ANT, computer technology can be regarded as the non-human agent that being utilized by the human actors, for example, the Korean multitudes. This network can thus be described as a collection of nodes, in which each node represents a single individual. These nodes would be able to bond together through using the internet forums. ICT have provided great ease with which these nodes could interact. Standards can also be exemplified from a "positive feedback" dynamic in which each new user increased the desirability of that standard in the eyes of the potential users. It is the positive feedback generated by the adoption of a standard that constitutes its "pull" that a standard has because it underlies a network of users to whom others are likely to want to gain access to "network power", which can "spread", propelled by people's desire for access to members of a network. A commonly used standard used in a network would be attractive to any outsiders wanting to gain access to that network and such outsiders may decide to adopt it for that purpose. We can see how online activity like this increased. Before the internet, a great deal of funds inevitably was needed to foster any type of demonstration and people had to gather in a single location to gather crucial information, exchange views, and mobilize. Then, the Internet, through the use of forums, single-handedly was able to substantially reduce these measures and at the same time improve the efficiency of gathering dispersed people together.

In 2008, when there was a fierce debate about whether the FTA should be ratified or not, on-line portal sites such as "Daum Agora" which is an online debate place and other Internet forums are estimated at more 
than $80 \%$ of the total number of Internet users. These forums substantially reduced the economic costs and time of mobilization. Forums are also formatted in ways that topics appearing on the main portal pages come up for social discussion among interested citizens over the online. In other words, debates are generated on-line, and portals often determine which topics should be discussed. They provide the venue for debate, and for lively exchanges of opinion.

The Agora online forum at the "Daum" web portal became the online center for discussion among citizens. For instance, from May 1, 2005 to November 7, 2008, there were 129,028 "Naver" blogs regarding mad cow disease and $95.3 \%$ of them were posted after the FTA process began. Also, "candlelight protests" and "beef" respectively composed 57\% and 50\% each in terms of online word searches. As more people sought information online and began posting their opinions on blogs and forums, this in turn increased the number of off-line protesters, which increased more blog postings and so forth, producing a self-reinforcing effect (Park, 2009).

On the other hand, there is another character to aggregate the opinion by new media is tweeter. There is no place to debate on the topic, but tweeter is faster and stronger than other media. For example, during the candlelight protest, from April to August in 2008, there are five times tweet than other periods. Also, it could be motivated to move people on the ground in Seoul. It should be crucial role to make the place where they can have collective movement and show public opinion to the government. In conclusion, nowadays, the media especially, in the online materials they become the important role to promote for public opinion and to motivate the protest which could send the public opinion to the government. This clearly shows the process of translation taking action as people used the non-human agent of the internet as their means to come together, spread awareness, share ideas, and begin mobilizing support against the government's foreign negotiation about FTA.

\section{The Struggle of Power Between the South Korean Government and the Public in the FTA Networks}

We can now bring together the large networks mentioned thus far into perspective as well as the struggle of power between them according to the ANT. This is the South Korean public, represented by individuals as nodes, which were being brought together through the Internet forum. This network could not act collectively and now exert a force powerful enough to oppose the ongoing FTA network through demonstrations. Though the candlelight protests were directed mainly at the South Korean president and his administration due to mistrust and miscommunication, the ongoing FTA negotiations and network process would be dealt a severe blow.

If the FTA ratification was finalized, this would mean the South Korean public would have no say in how this power would be imposed on them without their prior consultation. However, the multitude of nodes represented by the Korean protestors were able to use the non-human agent of the internet effectively to link with each other, mobilize together, and act collectively by ultimately protesting in the streets against the beef measures.

\section{The Role of Internet and New Media as Non-human Actors: Disorganizing the Black Box}

One of the most crucial features mentioned throughout this study is the concept of the black box, in which the masses do not possess the knowledge the politicians and experts possess. As the language of ANT, through the Internet, the network of the masses are exerted its power to try to open the black box which did hidden as 
the terms of the FTA. A black box suggested by Latour is "anything whose makeup can be taken for granted for present purposes", in which our case would be the FTA, since the two governments would initiate negotiations assuming that these measures would work out for the benefit of both US and South Korea.

The protesters demanded that the government made the negotiations more transparent by providing information, i.e., knowledge about the new beef measures. The multitudes were most of the time uninformed about the measures which were being negotiated by government officials and trade negotiators during the FTA process $^{1}$ which had been ongoing since the onset of the FTA process. Due to this black box, inevitable mistrust towards the government was bound to take place. To be specific, FTAs have been known to be handled directly between the governments of states themselves, though in many countries the public does have some leverage in participating during the FTA process, the power of trade agreements has been driven by the governments which have been the main factors behind such a trade networks.

However, the knowledge being transmitted back and forth between the two governments was largely hidden from the view of the South Korean people, which could be referred in this study as the "black box". It refers to the negotiation process where the politicians and experts possessed the knowledge among them and were a complete mystery to the Korean public trying to peer in. Nonetheless, the government tried to package and portrays the FTA to the Korean people pleasantly which would supposedly benefit both countries. Though this process of a one broadcasting company tried to reveal the unknown facts about this matter and this program became the starting point of opening the black box. After the show, there was a big argument on the topic on-line.

\section{The Results of After Opening the Black Box}

This great mistrust and miscommunication between the Korean multitudes and the government was clearly realized during the candlelight protests. The network of the multitude also exerted its power to try to pry open the black box of the FTA from which was forbidden. The protesters demand the government to reveal the transparent information, or knowledge of the FTA negotiation-beef measures to the public. To this extent, the candlelight protests were successful in hindering the governments' power invested in the FTA negotiations. Then, President Lee officially apologized to the South Korean public and after much consideration, gave into their demands. He and the administration party could not help but be awed by the impressive efforts demonstrated by the Korean public ${ }^{2}$.

As a results, the South Korean government was not able to control the people without gaining their trust, thus policy-making has no choice but to become more transparent and cooperative with the public. By the time the US and South Korea resumed talks of the FTA measures and had them ratified, President Lee deliberately left out the beef issue altogether, being weary of the public. Indeed, the Korean public, by being networked

\footnotetext{
${ }^{1}$ Once the beef issue was brought to candle light protest, Koreans became even more skeptical about the government which squandered its knowledge and did not reveal it to the outside. For example, the government rushed to end the beef deal with the US in consideration of the planned summit talks at Camp David. It attempted to open up the market to US beef including those from cattle over 30 months of age which were normally not consumed in the US while simultaneously trying to pacify the masses. Mistrust also grew since the multitudes continually felt that they could not communicate effectively with their own government as the police continued to arrest citizens during the protests. The people felt the president as one going against the will of the people and democracy (Lee, 2010).

${ }^{2}$ The ripple effects effectively reached US Congress as well as were mentioned in their official report: "Although the protests against the beef agreement subsided in the summer of 2008, they have had lingering effects on US-South Korean relations because of their erosion of President Lee's standing and because of their possible effects on the ratification of the FTA. The protests damaged the President's political strength and boosted the position of opposition groups that had been demoralized before the candlelight vigils" (The National Agricultural Law Center, 2008).
} 
together, had shaken the FTA measures sufficient enough to stifle progress for a notable period of time. The candlelight protests have proved that passive and politically distant Koreans actively took part in exerting the power against their governments as well as influencing international measures.

\section{Conclusion}

The Korean candlelight demonstrations were not merely domestic events between the Korean people and the government. It was a public network of people that was able to rise up and challenge an ongoing international negotiation process, the US and South Korea FTA. The openness of the internet and the online forums where average people could participate in proved that all major issues that the government advocates cannot be overlooked without their consensus.

During 2008, Korea has in fact proved that through the exchange of opinions from online space which truly led to the off-line protests in the streets of Seoul, people can create an impact on governance on an international scale. That is a major international network of trade established by the US and Korea through trade was disrupted by another network which was capitalized on by on-line forums. However, this still does not mean that power can be entirely shifted from the government to the public at a whim. Though the protests did stifle the Lee, Administration to a certain extent, in some sense the FTA efforts were not hindered greatly since South Korea eventually resumed imports of American beef into the country and FTA negotiations are moving forward.

Nonetheless, South Korea government did come to witness the spectacle of the power invested in public networked through the Internet and public spheres. It also realized the public has effective tools and means for objection if it chooses to use them. That being said, it must be seen how far this new embodiment of power through networks can put a check on not only domestic affairs, but in terms of international relations as well. In Sum, this paper focused more on how the public opinion was aggregate in the process, rather than the result. We can see that the role of non-human actors is highly important. In the past the public only received information that the government announced. However, through this attempt the citizen can reveal undisclosed information and get power to have communication with the government.

\section{References}

Anderson, J., Dean, J., \& Lovink, G. (2006). Reformatting politics: Information technology and global civil society. New York: Taylor and Francis Group.

Bernard. A., Jensen. J., Redding. S., \& Schott, P. (2009). The margins of US trade. National Bureau of Economic Research working paper 14662 .

Callon. M. (1986). Some elements of a sociology of translation: Domestication of the Scallops and the Fishermen of St. Brieuc Bay. In J. Law (Ed.), Power, action, and belief: A new sociology of knowledge (pp.196-223). London: Routledge and Kegan Paul.

Castells, M. (2009). Communication power. Oxford and New York: Oxford University Press.

Choi, Y. J. (2008). On-line public sphere and deliberative democracy: Civility and tolerance in the Anti-US beef internet protests in Korea. End of Journalism Conference, University of Bedfordshire, October 17-18.

Cowen, D., \& Carr, H. (2008). Actor network theory, implementation, and the private Landlord. Journal of Law and Society, 35, $149-166$.

Kim, S. (2002). Civil society and democratization. In C. K. Armstrong (Ed.), Korean society (pp. 92-105). London: Routledge.

Kim, Y. (2008). Digital populism in South Korea? Internet culture and the trouble with direct participation. Korea Economic Institute, 3(8), November.

Latour, B. (2005). Reassessing the social: An introduction to actor-network theory. Oxford University Press.

Law, J. (1992). Notes on the theory of the actor network: Ordering, strategy and heterogeneity. Systems Practice and Action 
Research, 5(4), 1-11.

Law, J., \& Hassard, J. (1999). Actor network theory and after. Oxford: Blackwell Publishers.

Lee, H. (2010). Trust in government and protectionism: Korean public opinion in the Korea-US free trade agreement. Canadian Political Science Association Annual Conference.

Lee, Y. (2007). Korea-US FTA and something perplexing in Korean cultural studies. Korean Journal of Communication Studies, 15(4), 97-122.

Miles, K. (2009). Networked politics: Agency, power, and governance. Cornell University Press.

Moaz, Z. (2004). Networks of nations: The evolution, structure, and effects of role of civil society in cyberspace. MIT Press: London.

Park, H. (2009). Trust and political activism in South Korea. 59th Political Studies Association Annual Conference, April 7-9.

Stepanova, E. (2011). The role of information communication technologies in the "Arab Spring"-Implications beyond the region. PONARS Eurasia Policy Memo, 159, 1-6.

\section{Appendix}

Table 1

Survey Results of 2008 Candlelight Protest in South Korea (Random Sampling Data)

\begin{tabular}{|c|c|c|}
\hline & Case & $\%$ \\
\hline Total & 1000 & 100.0 \\
\hline \multirow{3}{*}{$\begin{array}{l}\text { Male } \\
\text { Female }\end{array}$} & \multicolumn{2}{|c|}{ Gender } \\
\hline & 494 & 49.4 \\
\hline & 506 & 50.6 \\
\hline \multirow{6}{*}{$\begin{array}{l}19-29 \\
30-39 \\
40-49 \\
50-59 \\
60-\end{array}$} & \multicolumn{2}{|l|}{ Age } \\
\hline & 210 & 21.0 \\
\hline & 229 & 22.9 \\
\hline & 226 & 22.6 \\
\hline & 155 & 15.5 \\
\hline & 180 & 18.0 \\
\hline \multirow{6}{*}{$\begin{array}{l}\text { Under elementary school } \\
\text { Middle school } \\
\text { High school } \\
\text { Undergraduate } \\
\text { I don't know }\end{array}$} & \multicolumn{2}{|c|}{ Education } \\
\hline & \begin{tabular}{|l|}
71 \\
\end{tabular} & 7.1 \\
\hline & 80 & 8.0 \\
\hline & 292 & 29.2 \\
\hline & 529 & 52.9 \\
\hline & 29 & 2.9 \\
\hline
\end{tabular}

Source: The original data sources from "Sogang Institute of Political Studies" research are collected in 2008.

Table 2

The Reason for the On-going Participation in the Candlelight Protest

\begin{tabular}{|c|c|c|c|c|c|c|c|}
\hline Base & $\mathrm{N}$ & $\begin{array}{l}\text { The Danger } \\
\text { of US Beef }\end{array}$ & $\begin{array}{l}\text { The Failure of } \\
\text { government policy }\end{array}$ & $\begin{array}{l}\text { Aggregated Broad } \\
\text { Casting }\end{array}$ & $\begin{array}{l}\text { Propaganda of } \\
\text { opposite Party }\end{array}$ & I don't Know & Total \\
\hline Total & 1000 & 18.2 & 41.1 & 16.0 & 21.1 & 3.4 & 100.0 \\
\hline \multicolumn{8}{|l|}{ Gender } \\
\hline Male & 494 & 15.3 & 40.7 & 17.3 & 22.2 & 4.5 & 100.0 \\
\hline Female & 506 & 21.1 & 41.6 & 14.8 & 20.1 & 2.4 & 100.0 \\
\hline \multicolumn{8}{|l|}{ Age } \\
\hline $19-29$ & 210 & 20.1 & 46.1 & 17.3 & 13.9 & 2.6 & 100.0 \\
\hline $30-39$ & 229 & 17.9 & 54.8 & 11.9 & 12.1 & 3.2 & 100.0 \\
\hline $40-49$ & 226 & 17.6 & 44.0 & 15.6 & 22.1 & 0.7 & 100.0 \\
\hline 50-59 & 155 & 12.9 & 30.6 & 20.5 & 30.2 & 5.9 & 100.0 \\
\hline $60-$ & 180 & 21.8 & 23.6 & 16.4 & 32.2 & 6.0 & 100.0 \\
\hline \multicolumn{8}{|c|}{ Education } \\
\hline \multicolumn{2}{|c|}{ Elementary school } & 71 & 29.6 & 9.5 & 24.1 & 8.0 & 100.0 \\
\hline \multicolumn{2}{|c|}{ Middle school } & 80 & 30.1 & 20.3 & 23.6 & 3.3 & 100.0 \\
\hline
\end{tabular}




\begin{tabular}{|l|l|l|l|l|l|l|l|}
\hline High school & 292 & 20.4 & 37.1 & 16.1 & 23.5 & 2.9 & 100.0 \\
\hline Under graduate & 529 & 14.4 & 47.0 & 16.4 & 19.1 & 3.0 & 100.0 \\
\hline I don't know & 29 & 28.9 & 32.9 & 12.0 & 20.1 & 6.2 & 100.0 \\
\hline
\end{tabular}

Table 3

What do You Think of The Biggest Reason About the Candlelight Movement?

\begin{tabular}{|c|c|c|c|c|c|c|c|c|c|c|}
\hline Base & $\mathrm{N}$ & $\begin{array}{l}\text { Oppose } \\
\text { the FTA }\end{array}$ & $\begin{array}{l}\text { Against the } \\
\text { other policy }\end{array}$ & \begin{tabular}{|l} 
For \\
president \\
Impeach \\
-ment
\end{tabular} & $\begin{array}{l}\text { Show anger } \\
\text { to the } \\
\text { govern } \\
\text {-ment }\end{array}$ & $\begin{array}{l}\text { For } \\
\text { Companion } \\
\text {-ship }\end{array}$ & For fun & Other & $\begin{array}{l}\text { I don't } \\
\text { know }\end{array}$ & Total \\
\hline Total & 1000 & 20.3 & 25.4 & 7.3 & 32.9 & 1.6 & 5.8 & 3.9 & 2.8 & 100 \\
\hline \multirow{3}{*}{$\begin{array}{l}\text { Male } \\
\text { Female }\end{array}$} & \multicolumn{10}{|c|}{ Gender } \\
\hline & 494 & 20.1 & 26.0 & 6.7 & 30.8 & 1.5 & 7.0 & 4.7 & 3.2 & 100 \\
\hline & 506 & 20.6 & 24.9 & 7.9 & 34.9 & 1.6 & 4.6 & 3.2 & 2.4 & 100 \\
\hline \multirow{6}{*}{$\begin{array}{l}19-29 \\
30-39 \\
40-49 \\
50-59 \\
60-\end{array}$} & \multicolumn{10}{|l|}{ Age } \\
\hline & 210 & 16.0 & 21.9 & 4.5 & 47.7 & 1.1 & 5.4 & 2.3 & 1.1 & 100 \\
\hline & 229 & 24.2 & 21.6 & 3.3 & 41.9 & 1.0 & 4.0 & 3.7 & 0.4 & 100 \\
\hline & 226 & 21.1 & 26.9 & 7.6 & 30.0 & 1.5 & 7.2 & 4.5 & 1.2 & 100 \\
\hline & 155 & 19.1 & 28.7 & 12.6 & 24.6 & 0.0 & 50.9 & 40.1 & 50.0 & 100 \\
\hline & 180 & 20.8 & 29.9 & 10.6 & 14.7 & 4.2 & 6.6 & 5.3 & 8.0 & 100 \\
\hline \multicolumn{11}{|c|}{ Education } \\
\hline elementary & 71 & 30.9 & 32.1 & 11.0 & 4.8 & 4.1 & 4.3 & 6.1 & 6.7 & 100 \\
\hline $\begin{array}{l}\text { Middle } \\
\text { school }\end{array}$ & 80 & 27.5 & 24.3 & 8.1 & 21.2 & 5.0 & 5.3 & 2.2 & 6.5 & 100 \\
\hline High school & 292 & 21.6 & 23.0 & 8.2 & 34.5 & 1.5 & 5.4 & 3.3 & 2.4 & 100 \\
\hline $\begin{array}{l}\text { Under } \\
\text {-graduate }\end{array}$ & 529 & 17.1 & 26.1 & 6.3 & 38.1 & 0.5 & 6.0 & 4.4 & 1.3 & 100 \\
\hline I don't know & 29 & 21.7 & 25.0 & 3.8 & 20.8 & 4.5 & 9.5 & 0.0 & 14.7 & 100 \\
\hline
\end{tabular}

Table 4

Have You Ever Participated in the Candlelight Protest?

\begin{tabular}{|c|c|c|c|c|c|c|}
\hline Base & $\mathrm{N}$ & Yes & $\begin{array}{l}\text { I want to do, but } \\
\text { can't. }\end{array}$ & No & I don't know & Total \\
\hline Total & 1000 & 10.5 & 34.0 & 55.4 & 0.1 & 100 \\
\hline \multirow{3}{*}{$\begin{array}{l}\text { Male } \\
\text { Female }\end{array}$} & \multicolumn{6}{|c|}{ Gender } \\
\hline & 494 & 14.8 & 32.1 & 53.0 & 0.2 & 100 \\
\hline & 506 & 6.4 & 35.8 & 57.7 & 0.1 & 100 \\
\hline \multirow{6}{*}{$\begin{array}{l}19-29 \\
30-39 \\
40-49 \\
50-59 \\
60-\end{array}$} & \multicolumn{6}{|l|}{ Age } \\
\hline & 210 & 13.6 & 40.4 & 45.9 & 0.0 & 100 \\
\hline & 229 & 14.9 & 42.3 & 42.7 & 0.0 & 100 \\
\hline & 226 & 12.7 & 35.4 & 51.9 & 0.0 & 100 \\
\hline & 155 & 6.7 & 27.6 & 65.2 & 0.5 & 100 \\
\hline & 180 & 2.0 & 19.3 & 78.4 & 0.3 & 100 \\
\hline \multirow{6}{*}{$\begin{array}{l}\text { Under elementary } \\
\text { Middle school } \\
\text { High school } \\
\text { Undergraduate }\end{array}$} & \multicolumn{6}{|c|}{ Education } \\
\hline & 71 & 1.4 & 24.0 & 74.0 & 0.6 & 100 \\
\hline & 80 & 2.2 & 28.8 & 69.1 & 0.0 & 100 \\
\hline & 292 & 6.1 & 36.6 & 57.3 & 0.0 & 100 \\
\hline & 529 & 15.3 & 35.6 & 49.1 & 0.0 & 100 \\
\hline & 29 & 13.3 & 15.1 & 68.9 & 2.8 & 100 \\
\hline
\end{tabular}


Table 5

What do You Think of the Candlelight Protest?

\begin{tabular}{|c|c|c|c|c|c|c|c|c|c|}
\hline Base & $\mathrm{N}$ & $\begin{array}{l}\text { (1) Strongly } \\
\text { agree }\end{array}$ & (2) Agree & $(1)+(2)$ & (3) disagree & $\begin{array}{l}\text { (4) Strongly } \\
\text { disagree }\end{array}$ & $(3)+(4)$ & Non & Total \\
\hline Total & 1000 & 17.7 & 42.8 & 60.5 & 24.0 & 14.4 & 38.4 & 1.1 & 100 \\
\hline \multirow{3}{*}{$\begin{array}{l}\text { Male } \\
\text { Female }\end{array}$} & \multicolumn{9}{|c|}{ Gender } \\
\hline & 494 & 18.5 & 43.5 & 62.0 & 22.9 & 14.3 & 37.2 & 0.8 & 100 \\
\hline & 506 & 16.9 & 42.2 & 59.1 & 25.1 & 14.4 & 39.5 & 1.4 & 100 \\
\hline \multirow{6}{*}{$\begin{array}{l}19-29 \\
30-39 \\
40-49 \\
50-59 \\
60-\end{array}$} & \multicolumn{9}{|l|}{ Age } \\
\hline & 210 & 18.8 & 58.7 & 77.5 & 20.2 & 1.8 & 21.9 & 0.5 & 100 \\
\hline & 229 & 28.1 & 45.8 & 73.9 & 17.7 & 7.1 & 24.9 & 1.2 & 100 \\
\hline & 226 & 20.7 & 45.6 & 66.3 & 21.0 & 12.7 & 33.7 & 0.0 & 100 \\
\hline & 155 & 8.5 & 34.9 & 43.3 & 30.9 & 23.3 & 54.2 & 2.4 & 100 \\
\hline & 180 & 7.2 & 23.9 & 31.1 & 34.4 & 32.7 & 67.1 & 1.8 & 100 \\
\hline \multirow{5}{*}{$\begin{array}{l}\text { Under-elementary } \\
\text { Middle school } \\
\text { High school } \\
\text { Undergraduate }\end{array}$} & \multicolumn{9}{|c|}{ Education } \\
\hline & 71 & 9.5 & 27.3 & 36.8 & 34.7 & 27.0 & 61.7 & 1.5 & 100 \\
\hline & 80 & 7.0 & 30.1 & 37.2 & 42.2 & 17.9 & 60.1 & 2.7 & 100 \\
\hline & 292 & 17.2 & 41.0 & 58.2 & 18.9 & 21.5 & 40.4 & 1.3 & 100 \\
\hline & 529 & 20.6 & 48.4 & 69.0 & 22.7 & 7.7 & 30.4 & 0.5 & 100 \\
\hline I don't know & 29 & 18.3 & 32.7 & 51.0 & 23.6 & 22.6 & 46.2 & 2.8 & 100 \\
\hline
\end{tabular}

